\title{
Antibacterial activity of ethanol extract of Beluntas leaves on Streptococcus mutans, Porphyromonas gingivalis, and Enterococcus faecalis
}

\author{
Dini Sylvana ${ }^{1 *}$, Masyhudi Amir ${ }^{1}$, Cicih Bhakti Purnamasari ${ }^{1}$, Abdillah Iskandar ${ }^{1}$, Verry \\ Asfirizal ${ }^{2}$
}

\begin{abstract}
${ }^{1}$ Department of Microbiology, Faculty of Medicine Mulawarman University, Indonesia
\end{abstract}
${ }^{2}$ Department of Parasitology, Faculty of Medicine Mulawarman University, Indonesia

\begin{abstract}
Introduction: Individuals with poor oral health have a greater risk factor for systemic diseases. Caries, periodontal disease, and root canal infections are a common dental and oral diseases caused by dominance of Streptococcus mutans, Porphyromonas gingivalis, and Enterococcus faecalis bacteria (S. mutans, $P$. gingivalis, and $E$. faecalis). An alternative way to prevent dental and oral diseases is to use herbal medicine as one of the active ingredients for mouthwash or toothpaste. One of the herbs that can be used is Beluntas leaves (Pluchea indica (L.) Less leaves). The objective of study was to analyze the antibacterial activity of ethanol extract of Pluchea indica (L.) Less leaves on the growth of Streptococcus mutans, Porphyromonas gingivalis, and Enterococcus faecalis. Methods: This research was experimental laboratory with post test only control design, using disk diffusion method. There were five concentrations (2.5, 3.5, 4.5, 5.5 and $6.5 \%$, positive controls, and negative controls. Data analysis was performed using One Way Anova and post Hoc test. Results: The ethanol extract of Pluchea indica (L.) Less leaves has moderate-strong antibacterial activity against Streptococcus mutans, Porphyromonas gingivalis, and Enterococcus faecalis. The largest diameter of inhibitory zone in Enterococcus faecalis at a concentration of $6.5 \%$ followed by Streptococcus mutans and Porphyromonas gingivalis at the same concentration and the smallest diameter of inhibition zone in Porphyromonas gingivalis, followed by Enterococcus faecalis and Streptococcus mutans at $2.5 \%$ concentration. Conclusion: The ethanol extract of Pluchea indica (L.) Less leaves with a concentration of $2.5,3.5,4.5,5.5$, and $6.5 \%$ has antibacterial activity in inhibiting the growth of Streptococcus mutans, Porphyromonas gingivalis, and Enterococcus faecalis.
\end{abstract}

Keywords: Antibacterial activity, beluntas leaves, Enterococcus faecalis, Porphyromonas gingivalis, Streptococcus mutans.

p-ISSN: 1979-0201; e-ISSN: 2549-6212; Available from: http://jurnal.unpad.ac.id/pjd/article/view/15894

DOI: 10.24198/pid.vol33no1.15894

Submission: Feb 26, 2018; Accepted: Sep 10, 2021; Published online: Nov 30, 2021

*Corresponding author: Dini Sylvana, Department of Microbiology, Faculty of Medicine Mulawarman University, Indonesia Jalan. Kuaro, Gn. Kelua, Kec. Samarinda Ulu, Kota Samarinda, Kalimantan Timur 75119. Phone: +62 812-5554-9595 e-mail: sylvanadini@gmail.com 


\section{INTRODUCTION}

Dental and oral diseases, especially periodontitis can affect general body health. ${ }^{1}$ Individuals with poor oral health have a greater risk factor for systemic disorders than individuals with well maintained oral health. ${ }^{1}$ Dental and oral diseases such as caries and periodontal disease, are generally caused by pathogenic bacteria such as $S$. mutans, $P$. gingivalis, and $E$. faecalis in plaque and saliva. ${ }^{2}$

Prevention of dental and oral diseases can be done with plaque control using mouthwash. Mouth washing can help reduce plaque accumulation between teeth that are unreachable during brushing teeth. ${ }^{3}$ Antimicrobial ingredients in mouthwashes that are commonly used are chlorhexidine.

Chlorhexidine is a broad-spectrum antimicrobial agent that affects gram positive and gram negative bacteria, fungi and some viruses. ${ }^{4}$ However, chlorhexidine has some side effects, such as tooth staining, mucosal erosion, and causes an unpleasant feeling in the oral cavity. ${ }^{4}$

Alternative prevention methods that are being developed are using herbal medicine as one of the active ingredients for mouthwash or toothpaste. One of the herbs that can be used is Pluchea indica (L.) Less leaves.

Many people have used Pluchea indica (L.) Less leaves to eliminate body odor and bad breath, increase appetite, overcome digestive disorders in children and so on. ${ }^{5}$ Dayak Pesaguan tribes have used all parts of the Pluchea indica (L.) Less leaves as a medicine for body odor and digestion. ${ }^{6}$ In the research conducted by Nahak, ${ }^{5}$ ethanol extract of Pluchea indica (L.) Less leaves can inhibit the growth of bacteria S. mutans with a concentration of $25,50,75$ and $100 \%$. Pluchea indica (L.) Less leaves has strong to moderate antibacterial activity against $E$. faecalis and $F$. nucleatum bacteria. ${ }^{7}$

Pluchea (L.) Less leaves can also reduce the number of bacterial colonies in saliva with a concentration of $2.5,3.5,4.5,5.5$ and $6.5 \%{ }^{8}$ Objective of this study to analyze the antibacterial activity of ethanol extract of Pluchea indica (L.) Less leaves against Streptococcus mutans, Porphyromonas gingivalis, and Enterococcus faecalis using disk diffusion method. ${ }^{9}$

\section{METHODS}

This research was experimental laboratory with posttest only control design, using disk diffusion method. ${ }^{9}$ The tools used in this research were sterilization tool, preparation tool, inhibition zone measurement tool. The materials used in this research was Mueller-Hinton Agar (MHA) media, Mueller-Hinton Broth (MHB) media, Brain Heart Infusion Agar (BHIA) media, Brain Heart Infusion Broth (BHIB) media, bacteria, Mc Farland 0.5, Pluchea indica $L$. leaves extract.

The sample of this research was Streptococcus mutans ATCC 25175, Porphyromonas gingivalis ATCC 33277 and Enterococcus faecalis ATCC 29212.There are five concentration of Pluchea indica $L$. leaves extract $(2.5,3.5,4.5,5.5$ and $6.5 \%$, positive controls (Chlorhexidine $0.2 \%$ ), and negative controls (aquadest) with 4 times repetition. The results of the research data were processed by ANOVA and Post Hoc test.

\section{RESULTS}

The assessment of the antibacterial activity of ethanol extract of Pluchea indica (L.) Less leaves towards S. mutans, $P$. gingivalis, and $E$. faecalis growth was performed with the Kirby-Bauer agar diffusion method. ${ }^{9}$ The measurement results of the ethanol extract of Pluchea indica (L.) Less leaves antibacterial inhibitory zone towards $S$. mutans, $P$. gingivalis, and $E$. faecalis in 5 concentration and positive controls (Chlorhexidine $0.2 \%$ ), and negative controls (aquadest) tested were shown in Table 1.

Based on the results shown in Table 1, there were differences in the inhibitory zone of each sample. The biggest inhibitory area of ethanol extract of Pluchea indica (L.) Less leaves was found in $E$. faecalis bacteria at a concentration of $6.5 \%$ followed by $S$. mutans and $P$. gingivalis at the same concentration and the smallest inhibitory area was found in $P$. gingivalis bacteria, followed by $E$. faecalis and $S$. mutans at a concentration of $2.5 \%$.

Based on comparison test between variables, it was found that there were no significant differences ( $p>0.05)$ between concentrations of $5.5 \%$ and positive control in the S. mutans, between the concentrations of 2.5 and $3.5 \%$, between 4.5 and $5.5 \%$ in the $P$. gingivalis, 
and between the concentrations of 4.5 and $5.5 \%$, also between $4.5 \%$ and $5.5 \%$ on positive controls in the $E$. faecalis, the rest variables had significant values $(p<0.05)$.
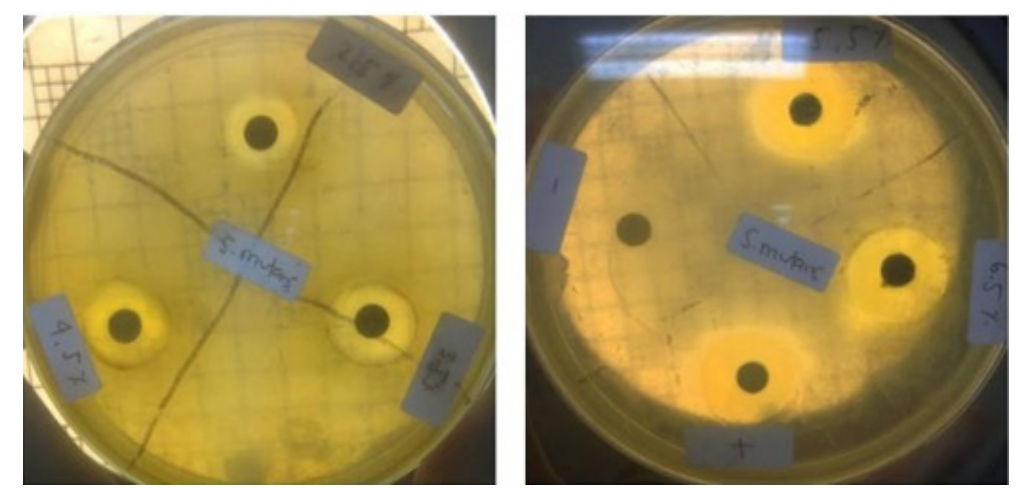

Figure 1. Antibacterial inhibitory zone of ethanol extract of Pluchea indica (L.) Less. leaves towards Streptococcus mutans
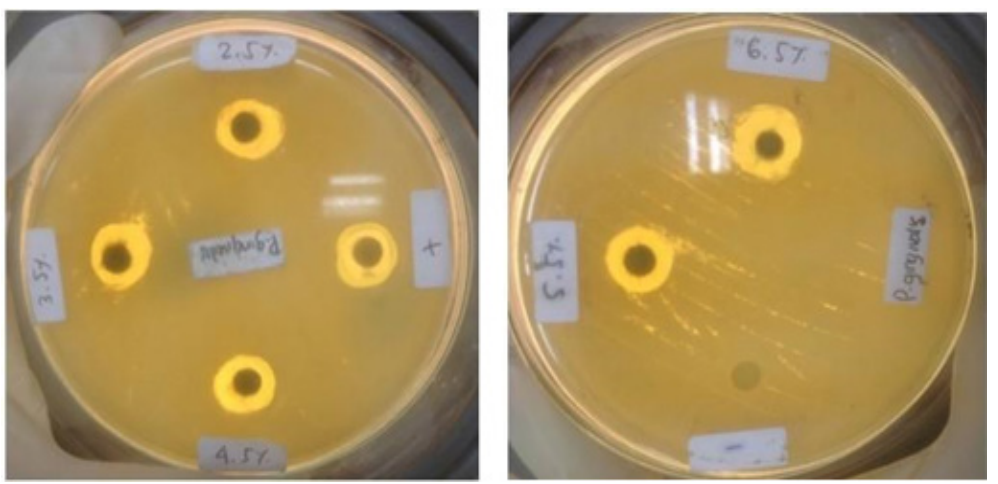

Figure 2. Antibacterial inhibitory zone of ethanol extract of Pluchea indica (L.) Less leaves towards Porphyromonas gingivalis
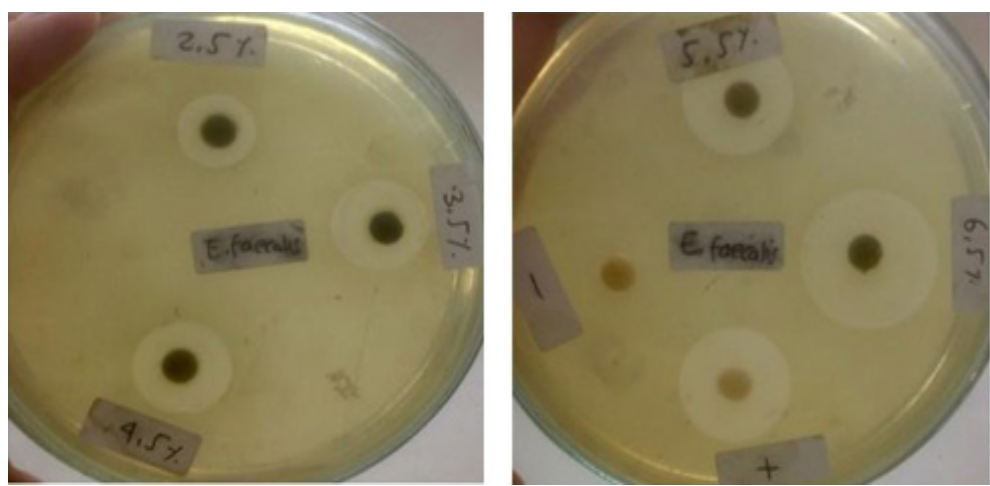

Figure 3. Antibacterial inhibitory zone of ethanol extract of Pluchea indica (L.) Less leaves towards Enterococcus faecalis

Table 1. The result of th he inhibitory zone measurement of ethanol extract of Pluchea indica (L.) Less leaves

\begin{tabular}{lccc}
\hline \multirow{2}{*}{ Concentration \% } & Streptococcus mutans & Porphyromonas gingivalis & Enterococcus faecalis \\
\cline { 2 - 4 } & Mean $(\mathrm{mm})$ & Mean $(\mathrm{mm})$ & Mean $(\mathrm{mm})$ \\
\hline Negative Control & $0.0 \pm 0.00$ & $0.0 \pm 0.00$ & $0.0 \pm 0.00$ \\
2.5 & $7.5 \pm 0.7$ & $5.3 \pm 0.4$ & $5.5 \pm 0.6$ \\
3.5 & $8.7 \pm 0.4$ & $5.5 \pm 0.2$ & $7.0 \pm 0.1$ \\
4.5 & $9.9 \pm 0.4$ & $6.5 \pm 0.2$ & $10.5 \pm 0.2$ \\
5.5 & $11.3 \pm 0.4$ & $6.9 \pm 0.3$ & $11.2 \pm 0.2$ \\
6.5 & $12.2 \pm 0.4$ & $8.8 \pm 0.1$ & $12.6 \pm 0.3$ \\
Positive Control & $11.4 \pm 0.8$ & $10.6 \pm 0.5$ & $10.9 \pm 0.5$ \\
\hline
\end{tabular}

Notes: Four times repetitions. The data is presented in mean \pm SEM. Disc diameter approximately $5 \mathrm{~mm}$. data were processed by ANOVA and Post Hoc test. 
Table 2. ANOVA result of the diameter of Streptococcus mutans inhibitory zone $(\mathrm{mm})$

\begin{tabular}{lccccc}
\hline & Sum of squares & df & Mean square & F & Sig. \\
\hline Between Groups & 64.751 & 5 & 12.950 & 66.534 & 0.000 \\
Within Groups & 3.503 & 18 & 0.195 & & \\
Total & 68.254 & 23 & & & \\
\hline
\end{tabular}

Table 3. ANOVA result of the diameter of Porphyromonas gingivalis inhibitory zone (mm)

\begin{tabular}{lccccc}
\hline & Sum of squares & $\mathrm{df}$ & Mean square & $\mathrm{F}$ & Sig. \\
\hline Between Groups & 86.132 & 5 & 17.226 & 268.034 & \multirow{2}{*}{0.000} \\
Within Groups & 1.157 & 18 & 0.064 & & \\
Total & 87.289 & 23 & & & \\
\hline
\end{tabular}

Table 4. ANOVA result of the diameter of Enterococcus faecalis inhibitory zone (mm)

\begin{tabular}{lccccc}
\hline & Sum of squares & df & Mean square & F & Sig. \\
\hline Between Groups & 150.053 & 5 & 30.011 & 234.494 & 0.000 \\
Within Groups & 2.304 & 18 & 0.128 & & \\
Total & 152.357 & 23 & & & \\
\hline
\end{tabular}

Table 5. Multiple comparisons of the inhibitory zone diameter of ethanol extract of of Pluchea indica (L.) Less leaves towards Streptococcus mutans $(\mathrm{mm})$ with Tukey HSD

\begin{tabular}{|c|c|c|c|c|c|c|}
\hline \multirow{2}{*}{ (I) Treatment } & \multirow{2}{*}{ (J) Treatment } & \multirow{2}{*}{$\begin{array}{c}\text { Mean difference } \\
(\mathrm{I}-\mathrm{J})\end{array}$} & \multirow{2}{*}{ Std. error } & \multirow{2}{*}{ Sig. } & \multicolumn{2}{|c|}{$95 \%$ confidence interval } \\
\hline & & & & & Lower bound & Upper bound \\
\hline \multirow{5}{*}{ Concentration of $2.5 \%$} & Concentration of $3.5 \%$ & $-1.24825^{*}$ & 0.31196 & 0.001 & -1.9037 & -0.5928 \\
\hline & Concentration of $4.5 \%$ & $-2.42750^{*}$ & 0.31196 & 0.000 & -3.0829 & -1.7721 \\
\hline & Concentration of $5.5 \%$ & $-3.84500^{*}$ & 0.31196 & 0.000 & -4.5004 & -3.1896 \\
\hline & Concentration of $6.5 \%$ & $-4.69000^{*}$ & 0.31196 & 0.000 & -5.3454 & -4.0346 \\
\hline & Positive control & $-3.90250^{*}$ & 0.31196 & 0.000 & -4.5579 & -3.2471 \\
\hline \multirow{5}{*}{ Concentration of $3.5 \%$} & Concentration of $2.5 \%$ & $1.24825^{*}$ & 0.31196 & 0.001 & 0.5928 & 1.9037 \\
\hline & Concentration of $4.5 \%$ & $-1.17925^{*}$ & 0.31196 & 0.001 & -1.8347 & -0.5238 \\
\hline & Concentration of $5.5 \%$ & $-2.59675^{*}$ & 0.31196 & 0.000 & -3.2522 & -1.9413 \\
\hline & Concentration of $6.5 \%$ & $-3.44175^{*}$ & 0.31196 & 0.000 & -4.0972 & -2.7863 \\
\hline & Positive control & $-2.65425^{*}$ & 0.31196 & 0.000 & -3.3097 & -1.9988 \\
\hline \multirow{5}{*}{ Concentration of $4.5 \%$} & Concentration of $2.5 \%$ & $2.42750^{*}$ & 0.31196 & 0.000 & 1.7721 & 3.0829 \\
\hline & Concentration of $3.5 \%$ & $1.17925^{*}$ & 0.31196 & 0.001 & 0.5238 & 1.8347 \\
\hline & Concentration of $5.5 \%$ & $-1.41750^{*}$ & 0.31196 & 0.000 & -2.0729 & -0.7621 \\
\hline & Concentration of $6.5 \%$ & $-2.26250^{*}$ & 0.31196 & 0.000 & -2.9179 & -1.6071 \\
\hline & Positive control & $-1.47500^{*}$ & 0.31196 & 0.000 & -2.1304 & -0.8196 \\
\hline \multirow{5}{*}{ Concentration of $5.5 \%$} & Concentration of $2.5 \%$ & $3.84500^{\star}$ & 0.31196 & 0.000 & 3.1896 & 4.5004 \\
\hline & Concentration of $3.5 \%$ & $2.59675^{*}$ & 0.31196 & 0.000 & 1.9413 & 3.2522 \\
\hline & Concentration of $4.5 \%$ & $1.41750^{*}$ & 0.31196 & 0.000 & 0.7621 & 2.0729 \\
\hline & Concentration of $6.5 \%$ & $-0.84500^{*}$ & 0.31196 & 0.014 & -1.5004 & -0.1896 \\
\hline & Positive control & -0.05750 & 0.31196 & 0.856 & -0.7129 & 0.5979 \\
\hline \multirow{5}{*}{ Concentration of $6.5 \%$} & Concentration of $2.5 \%$ & $4.69000^{*}$ & 0.31196 & 0.000 & 4.0346 & 5.3454 \\
\hline & Concentration of $3.5 \%$ & $3.44175^{*}$ & 0.31196 & 0.000 & 2.7863 & 4.0972 \\
\hline & Concentration of $4.5 \%$ & $2.26250^{*}$ & 0.31196 & 0.000 & 1.6071 & 2.9179 \\
\hline & Concentration of $5.5 \%$ & $0.84500^{*}$ & 0.31196 & 0.014 & 0.1896 & 1.5004 \\
\hline & Positive control & $0.78750^{*}$ & 0.31196 & 0.021 & 0.1321 & 1.4429 \\
\hline \multirow{5}{*}{ Positive control } & Concentration of $2.5 \%$ & $3.90250^{*}$ & 0.31196 & 0.000 & 3.2471 & 4.5579 \\
\hline & Concentration of $3.5 \%$ & $2.65425^{*}$ & 0.31196 & 0.000 & 1.9988 & 3.3097 \\
\hline & Concentration of $4.5 \%$ & $1.47500^{*}$ & 0.31196 & 0.000 & 0.8196 & 2.1304 \\
\hline & Concentration of $5.5 \%$ & 0.05750 & 0.31196 & 0.856 & -0.5979 & 0.7129 \\
\hline & Concentration of $6.5 \%$ & $-0.78750^{*}$ & 0.31196 & 0.021 & -1.4429 & -0.1321 \\
\hline
\end{tabular}


Table 5. Multiple comparisons of the inhibitory zone diameter of ethanol extract of of Pluchea indica (L.) Less leaves towards Porphyromonas gingivalis (mm) with Tukey HSD

\begin{tabular}{|c|c|c|c|c|c|c|}
\hline \multirow{2}{*}{ (I) Treatment } & \multirow{2}{*}{ (J) Treatment } & \multirow{2}{*}{$\begin{array}{c}\text { Mean difference } \\
(\mathrm{I}-\mathrm{J})\end{array}$} & \multirow{2}{*}{ Std. error } & \multirow{2}{*}{ Sig. } & \multicolumn{2}{|c|}{$95 \%$ Confidence interval } \\
\hline & & & & & Lower bound & Upper bound \\
\hline \multirow{5}{*}{ Concentration of $2.5 \%$} & Concentration of $3.5 \%$ & -0.22000 & 0.17926 & 0.818 & -0.7897 & 0.3497 \\
\hline & Concentration of $4.5 \%$ & $-1.21250^{*}$ & 0.17926 & 0.000 & -1.7822 & -0.6428 \\
\hline & Concentration of $5.5 \%$ & $-1.60750^{*}$ & 0.17926 & 0.000 & -2.1772 & -1.0378 \\
\hline & Concentration of $6.5 \%$ & $-3.49500^{*}$ & 0.17926 & 0.000 & -4.0647 & -2.9253 \\
\hline & Positive control & $-5.37000^{*}$ & 0.17926 & 0.000 & -5.9397 & -4.8003 \\
\hline \multirow{5}{*}{ Concentration of $3.5 \%$} & Concentration of $2.5 \%$ & 0.22000 & 0.17926 & 0.818 & -0.3497 & 0.7897 \\
\hline & Concentration of $4.5 \%$ & $-0.99250^{*}$ & 0.17926 & 0.000 & -1.5622 & -0.4228 \\
\hline & Concentration of $5.5 \%$ & $-1.38750^{*}$ & 0.17926 & 0.000 & -1.9572 & -0.8178 \\
\hline & Concentration of $6.5 \%$ & $-3.27500^{*}$ & 0.17926 & 0.000 & -3.8447 & -2.7053 \\
\hline & Positive control & $-5.15000^{*}$ & 0.17926 & 0.000 & -5.7197 & -4.5803 \\
\hline \multirow{5}{*}{ Concentration of $4.5 \%$} & Concentration of $2.5 \%$ & $1.21250^{*}$ & 0.17926 & 0.000 & 0.6428 & 1.7822 \\
\hline & Concentration of $3.5 \%$ & $0.99250^{*}$ & 0.17926 & 0.000 & 0.4228 & 1.5622 \\
\hline & Concentration of $5.5 \%$ & -0.39500 & 0.17926 & 0.283 & -0.9647 & 0.1747 \\
\hline & Concentration of $6.5 \%$ & $-2.28250^{*}$ & 0.17926 & 0.000 & -2.8522 & -1.7128 \\
\hline & Positive control & $-4.15750^{*}$ & 0.17926 & 0.000 & -4.7272 & -3.5878 \\
\hline \multirow{5}{*}{ Concentration of $5.5 \%$} & Concentration of $2.5 \%$ & $1.60750^{*}$ & 0.17926 & 0.000 & 1.0378 & 2.1772 \\
\hline & Concentration of $3.5 \%$ & $1.38750^{*}$ & 0.17926 & 0.000 & 0.8178 & 1.9572 \\
\hline & Concentration of $4.5 \%$ & 0.39500 & 0.17926 & 0.283 & -0.1747 & 0.9647 \\
\hline & Concentration of $6.5 \%$ & $-1.88750^{*}$ & 0.17926 & 0.000 & -2.4572 & -1.3178 \\
\hline & Positive control & $-3.76250^{*}$ & 0.17926 & 0.000 & -4.3322 & -3.1928 \\
\hline \multirow{5}{*}{ Concentration of $6.5 \%$} & Concentration of $2.5 \%$ & $3.49500^{*}$ & 0.17926 & 0.000 & 2.9253 & 4.0647 \\
\hline & Concentration of $3.5 \%$ & $3.27500^{\star}$ & 0.17926 & 0.000 & 2.7053 & 3.8447 \\
\hline & Concentration of $4.5 \%$ & $2.28250^{*}$ & 0.17926 & 0.000 & 1.7128 & 2.8522 \\
\hline & Concentration of $5.5 \%$ & $1.88750^{*}$ & 0.17926 & 0.000 & 1.3178 & 2.4572 \\
\hline & Positive control & $-1.87500^{*}$ & 0.17926 & 0.000 & -2.4447 & -1.3053 \\
\hline \multirow{5}{*}{ Positive control } & Concentration of $2.5 \%$ & $5.37000^{*}$ & 0.17926 & 0.000 & 4.8003 & 5.9397 \\
\hline & Concentration of $3.5 \%$ & $5.15000^{*}$ & 0.17926 & 0.000 & 4.5803 & 5.7197 \\
\hline & Concentration of $4.5 \%$ & $4.15750^{\star}$ & 0.17926 & 0.000 & 3.5878 & 4.7272 \\
\hline & Concentration of $5.5 \%$ & $3.76250^{*}$ & 0.17926 & 0.000 & 3.1928 & 4.3322 \\
\hline & Concentration of $6.5 \%$ & $1.87500^{*}$ & 0.17926 & 0.000 & 1.3053 & 2.4447 \\
\hline
\end{tabular}

Table 6. Multiple comparisons of the inhibitory zone diameter of ethanol extract of of Pluchea indica (L.) Less leaves towards Enterococcus faecalis (mm) with Tukey HSD

\begin{tabular}{|c|c|c|c|c|c|c|}
\hline \multirow[t]{2}{*}{ (I) Treatment } & \multirow[t]{2}{*}{ (J) Treatment } & \multirow{2}{*}{$\begin{array}{c}\text { Mean difference } \\
\text { (I-J) }\end{array}$} & \multirow[t]{2}{*}{ Std. error } & \multirow[t]{2}{*}{ Sig. } & \multicolumn{2}{|c|}{ 95\% Confidence interval } \\
\hline & & & & & Lower bound & Upper bound \\
\hline \multirow{5}{*}{ Concentration of $2.5 \%$} & Concentration of $3.5 \%$ & $-1.48000^{*}$ & 0.25296 & 0.000 & -2.2839 & -0.6761 \\
\hline & Concentration of $4.5 \%$ & $-4.93000^{*}$ & 0.25296 & 0.000 & -5.7339 & -4.1261 \\
\hline & Concentration of $5.5 \%$ & $-5.71500^{*}$ & 0.25296 & 0.000 & -6.5189 & -4.9111 \\
\hline & Concentration of $6.5 \%$ & $-7.06750^{*}$ & 0.25296 & 0.000 & -7.8714 & -6.2636 \\
\hline & Positive control & $-5.41750^{*}$ & 0.25296 & 0.000 & -6.2214 & -4.6136 \\
\hline \multirow{5}{*}{ Concentration of $3.5 \%$} & Concentration of $2.5 \%$ & $1.48000^{*}$ & 0.25296 & 0.000 & 0.6761 & 2.2839 \\
\hline & Concentration of $4.5 \%$ & $-3.45000^{*}$ & 0.25296 & 0.000 & -4.2539 & -2.6461 \\
\hline & Concentration of $5.5 \%$ & $-4.23500^{*}$ & 0.25296 & 0.000 & -5.0389 & -3.4311 \\
\hline & Concentration of $6.5 \%$ & $-5.58750^{*}$ & 0.25296 & 0.000 & -6.3914 & -4.7836 \\
\hline & Positive control & $-3.93750^{*}$ & 0.25296 & 0.000 & -4.7414 & -3.1336 \\
\hline
\end{tabular}




\begin{tabular}{|c|c|c|c|c|c|c|}
\hline \multirow[t]{2}{*}{ (I) Treatment } & \multirow[t]{2}{*}{ (J) Treatment } & \multirow{2}{*}{$\begin{array}{c}\text { Mean difference } \\
\text { (I-J) }\end{array}$} & \multirow[t]{2}{*}{ Std. error } & \multirow[t]{2}{*}{ Sig. } & \multicolumn{2}{|c|}{$95 \%$ Confidence interval } \\
\hline & & & & & Lower bound & Upper bound \\
\hline \multirow{5}{*}{ Concentration of $4.5 \%$} & Concentration of $2.5 \%$ & $4.93000^{*}$ & 0.25296 & 0.000 & 4.1261 & 5.7339 \\
\hline & Concentration of $3.5 \%$ & $3.45000^{*}$ & 0.25296 & 0.000 & 2.6461 & 4.2539 \\
\hline & Concentration of $5.5 \%$ & -0.78500 & 0.25296 & 0.058 & -1.5889 & 0.0189 \\
\hline & Concentration of $6.5 \%$ & $-2.13750^{*}$ & 0.25296 & 0.000 & -2.9414 & -1.3336 \\
\hline & Positive control & -0.48750 & 0.25296 & 0.418 & -1.2914 & 0.3164 \\
\hline \multirow{5}{*}{ Concentration of $5.5 \%$} & Concentration of $2.5 \%$ & $5.71500^{*}$ & 0.25296 & 0.000 & 4.9111 & 6.5189 \\
\hline & Concentration of $3.5 \%$ & $4.23500^{*}$ & 0.25296 & 0.000 & 3.4311 & 5.0389 \\
\hline & Concentration of $4.5 \%$ & 0.78500 & 0.25296 & 0.058 & -0.0189 & 1.5889 \\
\hline & Concentration of $6.5 \%$ & $-1.35250^{*}$ & 0.25296 & 0.001 & -2.1564 & -0.5486 \\
\hline & Positive control & 0.29750 & 0.25296 & 0.842 & -0.5064 & 1.1014 \\
\hline \multirow{5}{*}{ Concentration of $6.5 \%$} & Concentration of $2.5 \%$ & $7.06750^{*}$ & 0.25296 & 0.000 & 6.2636 & 7.8714 \\
\hline & Concentration of $3.5 \%$ & $5.58750^{*}$ & 0.25296 & 0.000 & 4.7836 & 6.3914 \\
\hline & Concentration of $4.5 \%$ & $2.13750^{*}$ & 0.25296 & 0.000 & 1.3336 & 2.9414 \\
\hline & Concentration of $5.5 \%$ & $1.35250^{*}$ & 0.25296 & 0.001 & 0.5486 & 2.1564 \\
\hline & Positive control & $1.65000^{*}$ & 0.25296 & 0.000 & 0.8461 & 2.4539 \\
\hline \multirow{5}{*}{ Positive control } & Concentration of $2.5 \%$ & $5.41750^{*}$ & 0.25296 & 0.000 & 4.6136 & 6.2214 \\
\hline & Concentration of $3.5 \%$ & $3.93750^{*}$ & 0.25296 & 0.000 & 3.1336 & 4.7414 \\
\hline & Concentration of $4.5 \%$ & 0.48750 & 0.25296 & 0.418 & -0.3164 & 1.2914 \\
\hline & Concentration of $5.5 \%$ & -0.29750 & 0.25296 & 0.842 & -1.1014 & 0.5064 \\
\hline & Concentration of $6.5 \%$ & $-1.65000^{*}$ & 0.25296 & 0.000 & -2.4539 & -0.8461 \\
\hline
\end{tabular}

\section{DISCUSSION}

The inhibitory zone diameters of each sample interpreted based on Davis \& Stout (1971) criteria, where the diameter of the inhibitory zone divided into three categories: 1) weak, if the diameter of the inhibitory zone of less than $10 \mathrm{~mm}, 2$ ) moderate, if the diameter of the inhibitory zone $10-20 \mathrm{~mm}$ and 3) Strong, if the diameter of the inhibitory zone of more than $20 \mathrm{~mm} \cdot{ }^{10}$ According to Table 1 , the result showed that the ethanol extract Pluchea indica (L.) Less leaves had moderate-strong antibacterial activity towards $S$. mutans, $P$. gingivalis dan $E$. faecalis bacteria.

Strong antibacterial activity is only found at concentrations of $5.5 \%$ and $6.5 \%$ against $S$. mutans and E. Faecalis bacteria, and the other concentrations have moderate activity. This finding was equivalent to previous studies by Syafira, that showed ethanol extract of Pluchea indica (L.) Less could reduce the number of bacteria in saliva, where at a concentration of $5.5 \%$ and $6.5 \%$ the results were equivalent to positive control, chlorhexidine gluconate $0.2 \%$, which there is no colonies of bacteria grown. ${ }^{8}$
Inhibitory zone of ethanol extract of Pluchea indica (L.) Less leaves increased according to the increase in concentration of extracts tested on S. mutans and E. faecalis. This finding was caused by the amount of the active compounds contained in the luchea indica (L.) Less leaves extract. The higher concentration of the extract, the broader its inhibitory zone towards the growth of the bacterias. ${ }^{11,12}$ Antibacterial ability of ethanol extract of Pluchea indica (L.) Less related to the active compounds which is flavonoids, phenolics, tannins, alkaloids, lignin glycosides, and triterpenoids that are bacteriostatic and bactericidal. ${ }^{5,13}$ Flavonoids work as antibacterials in several ways, such as, inhibiting bacterial cell wall synthesis, membrane disruption, inhibit bacterial protein synthesis, and inhibition of nucleic acid synthesis. ${ }^{14}$ The mechanism of phenol was by denaturing the bacterial cell protein. ${ }^{13,15}$ Tanin has an antibacterial effect by forming a complex with proline which is a type of protein in the cell wall of bacteria, which causes protein leakage and damage to bacterial cell walls. ${ }^{8,13}$ Alkaloid compounds have inhibitory mechanisms by interfering the constituent 
components of peptidoglycan in bacterial cells, so the cell wall layer is not formed intact and causes cell death. In addition, in the alkaloid compound there is a nitrogen-containing base group that will act and affect bacterial DNA. This reaction results in changes in the structure and arrangement of amino acids, which will cause damage and encourage bacterial cell lysis. ${ }^{15}$

However the results from $P$. gingivalis bacteria showed there were no significant differences at the concentrations of $2.5 \%$ and $3.5 \%$ and at concentrations of $4.5 \%$ and $5.5 \%$. There are multiple contributing factors that affect the inhibitory zone, in which are the amount of bacteria being used, bacterial growth speed, bacterial sensitivity, type of bacteria, toxicity of the test material, temperature and the interaction between medium and micro-environment in vitro. ${ }^{11,16,17}$

P. gingivalis also has a smallest inhibitory zone diameter compared to $S$. mutans and $E$. faecalis. This may occur because of the composition of the cell wall $P$. gingivalis. The Gram negative bacteria's cell wall was more complex than Gram positive so it is difficult for the active compounds of Beluntas leaves to penetrate the cell wall. Gram negative and positive bacteria have differences in cell wall components. ${ }^{11,18}$

Gram negative bacteria has endotoxins in the form of lipopolysaccharide complexes on their cell walls, and double membranes in which the plasma membrane is surrounded by a permeable outer membrane and the middle part of the membrane is peptidoglycan. ${ }^{11,18}$ In the previous study by Suhartono also showed that there were differences activity of ethanol extract of Pluchea indica (L.) Less in inhibiting the growth of Escherichia coli bacteria, which also Gramnegative bacteria. ${ }^{19}$

In this study, there were differences in activity strength between ethanol extract of beluntas leaves and amoxicillin, where the active compounds of Pluchea indica (L.) Less leaves was difficult to penetrate into the cell wall of gram negative bacteria compared to amoxicillin. ${ }^{19}$ This research is also in accordance with research by Wibowo, where the extract of Plumeria acuminata Ait has the lower ability to inhibit the growth of $P$. gingivalis compared to $S$. mutans and $E$. faecalis. ${ }^{20}$

\section{CONCLUSIONS}

The ethanol extract of Pluchea indica (L.) Less with a concentration of $2.5,3.5,4.5,5.5$, and $6.5 \%$ has antibacterial activity in inhibiting the growth of Streptococcus mutans, Porphyromonas gingivalis, and Enterococcus faecalis.

\section{REFERENCES}

1. Nazir MA. Prevalence of periodontal disease, its association with systemic diseases and prevention. Int J Health Sci (Qassim). 2017; 11(2): 72-80.

2. Caranza, FA, Newman MG, Takei HH, Klokkevold PR. Carranza's Clinical Periodontology $12^{\text {th }}$ ed. China: Saunders Elsevier; 2015. p. 994.

3. Anita P, Sivasamy S, Madan Kumar PD, Balan IN, Ethiraj S. In vitro antibacterial activity of Camellia sinensis extract against cariogenic microorganisms. J Basic Clin Pharm. 2014; 6(1): 35-9. DOI: 10.4103/0976-0105.145777.

4. Rath S, Singh MM. Comparative Clinical and Microbiological Efficacy of Mouthwashes Containing $0.2 \%$ and $0.12 \%$ Clorhexidine. Dent Res J (Isfahan). 2013; 10(3): 364-9.

5. Nahak, M. M. Beluntas Leaf Extract (Puchea indica L) to Inhibit Growth of Streptococcus mutans. J Dent Heal. 2013; 1(1): 40-50. DOI: 10.30659/odj.5.1.28-33

6. Due R, Symaswisna, Marlina R. Ethnobotany of dayak pesaguan medicinal plant and its implementation in the making of biodiversity flash cards. Biological study of faculty of teacher training and education untan pontianak. 2013; 3(2): 1-15.

7. Pargaputr FA, Munadziroh E, Indrawati R. Antibacterial effects of Pluchea indica Less leaf extract on $\mathrm{E}$. faecalis and Fusobacterium nucleatum (in vitro). Dent J. 2016; 49(2): 9398. DOI: $10.20473 / j . d j m k g . v 49 . i 2 . p 93-98$

8. Syafira AF. In Vitro Efficacy of Ethanol Extract of Beluntas Leaves (Pluchea indica (L.) Less.) towards Bacteria in Saliva. ODONTO Dental Journal. 2019; 6(2): 68-75. DOI: 10.30659/ odj.6.2.68-75

9. Balouiri M, Sadiki M, Ibnsouda SK. Methods for in vitro evaluating antimicrobial activity: A review. J Pharm Anal. 2016; 6(2): 71-79. DOI: 
10.1016/j.jpha.2015.11.005

10. Ulpiyah, Zakiyya, Shita, Amandia, Wahyukundari, Melok Aris. Inhibition of namnam (Cynometra cauliflora L.)leaves extract on the growth of Porphyromonas gingivalis. Padj J Dent. 2019; 31(2): 106-11. DOI: $10.24198 / \mathrm{pjd}$. vol31no2.18540

11. Pelczar M, Chan E. Elements of microbiology. Translated by hadioetomo $r s$, imas $t$, tjitrosomo ss, angka sl. Jakarta: Universitas Indonesia Press; 2013.

12. Armedita, D. The antibacterial activity of leaves ethanol extract, stem bark, and latex of angsana (pterocarpus indicus willd.) Towards bacterial growth streptococcus mutans as in vitro. ODONTO Dent J. 2018: 5(1): 1-8. DOI: 10.30659/odj.5.1.1-8

13. Nahak MM, Tedjasulaksana $R$, Sumerti NN. Ability difference of beluntas leaf (pluchea indica l) ethanol extract and avocado leaf (persea americana mill) ethanol extract in inhibiting caries-causing streptococcus mutans bacteria growth. Bali Med J. 2017; 6(3): 38790. DOI: $10.15562 / \mathrm{bmj} . v 6 i 3.742$

14. Górniak, I., Bartoszewski, R. \& Króliczewski, J. Comprehensive review of antimicrobial activities of plant flavonoids. Phytochem Rev 2019; 18: 241-72. DOI: 10.1007/s11101-0189591-z

15. Cushnie, Tim, Cushnie, Benjamart, Lamb,
Andrew. Alkaloids: An overview of their antibacterial, antibiotic-enhancing and antivirulence activities. International Journal of Antimicrobial Agents. 2014; 44(5): 377-386. DOI: $10.1016 / j . i j a n t i m i c a g .2014 .06 .001$

16. Li J, Xie S, Ahmed S, Wang F, Gu Y, Zhang C, Chai $X$ et al. Antimicrobial activity and resistance: influencing factors. Front pharmacol. 2017;8: 364. DOI: 10.3389/fphar.2017.00364

17. Aziz, \& Cahyadi, J. Benefits of tiwai onion (eleutherine americana) extract as a phytopharmaceutical plant to inhibit the growth of bacteria vibrio harveyi through invitro and in-vivo. J Ilmiah Perikanan Kelautan. 2020; 12(1): 105-112. DOI: 10.20473/jipk. v12i1.12826

18. Jawetz M. Medical Microbiology $25.25^{\text {th }}$ ed. Jakarta: EGC; 2012. p. 112.

19. Dubreuil JD. Antibacterial and antidiarrheal activities of plant products against enterotoxigenic Escherichia coli. Toxins (Basel). 2013; 5(11): 2009-41. DOI: $10.3390 /$ toxins5112009.

20. Patra JK, Kim ES, Oh K, Kim HJ, Kim Y, Baek $\mathrm{KH}$. Antibacterial effect of crude extract and metabolites of Phytolacca americana on pathogens responsible for periodontal inflammatory diseases and dental caries. BMC Complement Altern Med. 2014; 14 :343. DOI: 10.1186/1472-6882-14-343. 